\section{Scientists involved in Armenian environmental demonstrations}

\section{London}

SciENTISTs and cultural workers helped coordinate the Armenian demonstrations in Erevan last week, according to Sergei Grigoryants, editor of the unofficial Moscow journal Glasnost. Grigoryants, himself half-Armenian, managed to visit Erevan for two days during the demonstrations, and brought out a video film which confirmed both the size of the demonstrations (several hundred thousand people) and the good order that the organizing committee kept.

The identity of these scholars has not yet emerged, but they are probably among the 350 Armenian academics and intellectuals who in March 1986 launched a major environmental campaign in Armenia with their open letter to Mr Gorbachev protesting against growing levels of pollution in the Armenian republic. Throughout the Soviet Union, the policy of glasnost has generated many semi-official "citizens' initiatives" in defence of the environment, and in almost every case, many of those most vocal about existing or impending environmental hazards are equally active in "national" campaigns which the authorities find less acceptable. Even in the Russian SFSR, the campaign against the diversion of the Siberian rivers was spearheaded by the group of writers known collectively as the "villagers" who stress the importance of Russian traditions and values and who saw the diversion as a threat to irreplaceable Russian archaeological treasures. In the non-Russian republics, the link is still more strongly marked. Many Estonians, for example, see the environmental threat from the development of the phosphorite industry and the ethnic threat from the influx of Russian workers (which could make the Estonians a minority in their own republic) as two aspects of one problem.

In the case of Armenia and the "national" demonstrations calling for the transfer of the Nagorno-Karabakh autonomous region from Azerbaijan to Armenia, the original impetus seems to have come directly from an ecological protest. On 17 October 1987, there was a protest meeting outside the Nairit calcium carbide plant in Erevan, whose managers had persistently and flagrantly ignored the anti-pollution laws. This demonstration had the approval of the local party authorities, and took place peacefully. Its success, however, inspired about a thousand of the participants to stage a second demonstration the next day, demanding the restoration to Armenia of NagornoKarabakh. This time, the demonstrators, who had hoped to march to the headquarters of the Armenian Communist party, were dispersed by the police first.

In spite of the attempted demonstration in October, last week's events, first in Nagorno-Karabakh itself and then in Erevan, seem to have taken Moscow by surprise. Official commentators gave widely varying estimates of the ethnic composition of the Nagorno-Karabakh region, ranging from "a predominantly Armenian population" (TASS) to "18 per cent Armenian" (Moscow radio world service). (Western estimates put it at around 75 per cent Armenian.) The quality of life in the region also seems unclear: the deputy chairman of Azerbaijan's Council of Ministers, Ayaz Mutabilov, said that in many fields of the economy and culture, Nagorno-Karabakh has "higher indicators than the average for Azerbaijan", whereas Mr Gorbachev, in his message to the peoples of Armenia and Azerbaijan, spoke of the many "shortcomings and difficulties" which have, he said, accumulated in the region.

The Armenian demonstrators have now announced a month's moratorium. The problem for the Soviet government is, however, wider than that of perhaps redrawing the boundaries of the Armenian and Azerbaijanian republics. Ethnic consciousness is on the increase everywhere in the Soviet Union, not only in traditional centres of national dissent such as the Ukrainian and Lithuanian republics, but also, for example, in Uzbekistan (centred on the Uzbek writers' campaign to save the Aral Sea), and in Byelorussia, where, wide network of informal groups has sprung up, focused on the native language, the "blank spots" of history and environmental problems. Ecological concern, once seen as one of the "safest" topics for glasnost, is taking on "nationalist" overtones.

The Soviet authorities have so far simply issued warnings about what are and are not suitable subjects for protest, with the environmental still in the "permitted" category. In Czechoslovakia, however, the environment is seen as having a "political dimension", and a legally constituted environmental group in Bratislava, called Nahlas, has recently come under sharp criticism from the party for having compiled an extensive report on the state of the city's environment on the grounds that such information could play into the hands of anti-socialists abroad. The members of Nahlas (the name means "Speak up!") consider this criticism unfounded and, it is understood, are hoping to make their case known to like-minded groups of environmentalists within the Soviet Union.

Vera Rich after decades of ethnic inertia, a republic-

\section{Outlook poor for agriculture \\ London}

Agricultural research in Britain is destined to remain inadequately financed for at least the next five years, despite increasing investment from the private sector. In its 1988 corporate plan, published this week, the Agricultural and Food Research Council (AFRC) predicts that its total income will increase annually by around 3 per cent for the next five years, which is insufficient to meet rising costs.

AFRC, which has recently undergone a period of radical restructuring, has borne the brunt of government cutbacks in research funding over the past five years. Since 1983 , AFRC has shed around 25 per cent of its workforce, one-third of those by compulsory redundancy, to its present total of 4,881 . This number is expected to decline further to 4,540 by $1990-91$, before increasing slightly to 4,680 by 1992-93, mainly due to an increasing proportion of period appointments supported by outside industry.

Funding from government has declined by 20 per cent in real terms since $1983-84$ to the present level, including commissioned research from other government departments, of $£ 98$ million. Contracts from the Ministry of Agriculture, Fisheries and Food (MAFF) amount to around $£ 45$ million annually. But a cut in MAFF's research budget will result in a decrease of $£ 4$ million over the next two years for AFRC.

Income from commercial sources and other government departments presently stands at $£ 14$ million, with a projected increase to $£ 22$ million by $1992-93$, when it will amount to 20 per cent of the council's total income.

The council will increase its support of research in universities, at present $£ 7.5$ million. After 1988-89, the level of grants committed will be increased by 4 per cent annually. Until now, however, AFRC has maintained its support of university research at the expense of the budgets of its own institutes. The present corporate plan warns that from now on university support could be limited.

Much of the university support is intended eventually to be channelled through interdisciplinary research centres. Bids are now being invited from institutions to host a centre in one of eight topics of strategic importance.

In the institutes, programmes will be reshaped over the next few years, with greater emphasis given to molecular biology and genetics in plant sciences and animal physiology, horticulture and engineering. Reductions will be made in support given to aspects of arable crops, grassland and animal production, and animal health. 